\title{
Front Matter: Volume 8754
}

, "Front Matter: Volume 8754," Proc. SPIE 8754, Open Architecture/Open Business Model Net-Centric Systems and Defense Transformation 2013, 875401 (19 June 2013); doi: 10.1117/12.2032075

Event: SPIE Defense, Security, and Sensing, 2013, Baltimore, Maryland, SPIE. United States 


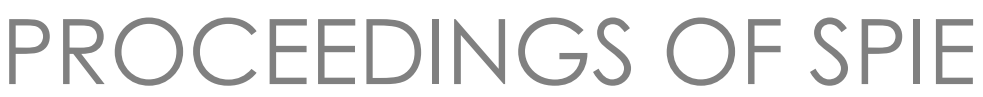

\title{
Open Architecture/Open Business Model Net-Centric Systems and Defense Transformation 2013
}

\author{
Raja Suresh \\ Editor
}

30 April-1 May 2013

Baltimore, Maryland, United States

Sponsored and Published by

SPIE 
The papers included in this volume were part of the technical conference cited on the cover and title page. Papers were selected and subject to review by the editors and conference program committee. Some conference presentations may not be available for publication. The papers published in these proceedings reflect the work and thoughts of the authors and are published herein as submitted. The publisher is not responsible for the validity of the information or for any outcomes resulting from reliance thereon.

Please use the following format to cite material from this book:

Author(s), "Title of Paper," in Open Architecture/Open Business Model Net-Centric Systems and Defense Transformation 2013, edited by Raja Suresh, Proceedings of SPIE Vol.8754 (SPIE, Bellingham, WA, 2013) Article CID Number.

ISSN: 0277-786X

ISBN: 9780819498113

Published by

SPIE

P.O. Box 10, Bellingham, Washington 98227-0010 USA

Telephone +1 3606763290 (Pacific Time) · Fax +1 3606471445

SPIE.org

Copyright (C) 2013, Society of Photo-Optical Instrumentation Engineers.

Copying of material in this book for internal or personal use, or for the internal or personal use of specific clients, beyond the fair use provisions granted by the U.S. Copyright Law is authorized by SPIE subject to payment of copying fees. The Transactional Reporting Service base fee for this volume is $\$ 18.00$ per article (or portion thereof), which should be paid directly to the Copyright Clearance Center (CCC), 222 Rosewood Drive, Danvers, MA 01923. Payment may also be made electronically through CCC Online at copyright.com. Other copying for republication, resale, advertising or promotion, or any form of systematic or multiple reproduction of any material in this book is prohibited except with permission in writing from the publisher. The CCC fee code is 0277-786X/13/\$18.00.

Printed in the United States of America.

Publication of record for individual papers is online in the SPIE Digital Library.

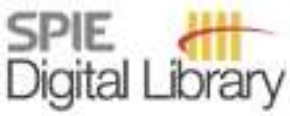

SPIEDigitalLibrary.org

Paper Numbering: Proceedings of SPIE follow an e-First publication model, with papers published first online and then in print and on CD-ROM. Papers are published as they are submitted and meet publication criteria. A unique, consistent, permanent citation identifier (CID) number is assigned to each article at the time of the first publication. Utilization of CIDs allows articles to be fully citable as soon as they are published online, and connects the same identifier to all online, print, and electronic versions of the publication. SPIE uses a six-digit CID article numbering system in which:

- The first four digits correspond to the SPIE volume number.

- The last two digits indicate publication order within the volume using a Base 36 numbering

system employing both numerals and letters. These two-number sets start with 00, 01, 02, 03, 04, $05,06,07,08,09,0 A, 0 B \ldots$. 0Z, followed by 10-1Z, 20-2Z, etc.

The CID Number appears on each page of the manuscript. The complete citation is used on the first page, and an abbreviated version on subsequent pages. Numbers in the index correspond to the last two digits of the six-digit CID Number. 


\title{
Contents
}

\author{
$\checkmark$ Conference Committee \\ vii Introduction
}

\section{PERSPECTIVES ON OPEN ARCHITECTURE/OPEN BUSINESS MODEL (OA/OBM) SYSTEMS}

875402 Naval open systems architecture (Invited Paper) [8754-1]

N. Guertin, B. Womble, V. Haskell, U.S. Navy (United States)

875404 The UAS control segment architecture: an overview (Invited Paper) [8754-4]

D. A. Gregory, P. Batavia, Neya Systems LLC (United States); M. Coats, General Dynamics C4 Systems (United States); C. Allport, NewSpin Robotics (United States); A. Jennings, Dynetics Inc. (United States); R. Ernst, Office of the Secretary of Defense AT\&L Unmanned Warfare (United States)

875406 A model for open architecture mission control systems (Invited Paper) [8754-6]

T. J. Pavlick, IBM Corp. (United States)

\section{NET-CENTRIC ARCHITECTURES AND INFORMATION ASSURANCE}

875409 Evaluating encrypted Boolean functions on encrypted bits: secure decision-making on the black side [8754-10]

R. Krishnan, Cosocket LLC (United States); R. Sundaram, Northeastern Univ. (United States)

Author Index 
Proc. of SPIE Vol. $8754875401-4$

Downloaded From: https://www.spiedigitallibrary.org/conference-proceedings-of-spie on 26 Apr 2023 Terms of Use: https://www.spiedigitallibrary.org/terms-of-use 


\section{Conference Committee}

Symposium Chair

Kenneth R. Israel, Major General (USAF Retired) (United States)

Symposium Cochair

David A. Whelan, Boeing Defense, Space, and Security

(United States)

Conference Chair

Raja Suresh, General Dynamics Advanced Information Systems (United States)

Conference Program Committee

Vasu D. Chakravarthy, Air Force Research Laboratory (United States)

Megan Cramer, U.S. Navy PEO LCS (United States)

John S. Eicke, U.S. Army Research Laboratory (United States)

Bassam S. Farroha, U.S. Department of Defense (United States)

Deborah Farroha, U.S. Department of Defense (United States)

Gayle D. Grant, U.S. Army Communications-Electronics Command (United States)

Thomas Green, SAIC (United States)

Michael A. Kolodny, U.S. Army Research Laboratory (United States)

Andrew Morrison, Metron, Inc. (United States)

Leo J. Rose, U.S. Air Force (United States)

Jason R. Stack, Office of Naval Research (United States)

Session Chairs

1 Perspectives on Open Architecture/Open Business Model (OA/OBM)

Systems

Megan Cramer, U.S. Navy PEO LCS (United States)

Jason R. Stack, Office of Naval Research (United States)

2 Net-centric Architectures and Information Assurance

Andrew Morrison, Metron, Inc. (United States)

Bassam S. Farroha, U.S. Department of Defense (United States) 
3 Open Architecture (OA)/Open Business Model (OBM) Systems: Joint Session with Conferences 8741 and 8754

Raja Suresh, General Dynamics Advanced Information Systems (United States)

Douglas W. Gage, XPM Technologies (United States)

4 Networking for Netcentric Warfare: Joint Session with Conferences 8742 and 8754

Raja Suresh, General Dynamics Advanced Information Systems (United States)

Tien Pham (United States)

Special Workshop and Discussion on Modular Open System

Architecture (MOSA) Back End for RF Systems (MBE-RF)

Edwin Culpepper, Moderator, Air Force Research Laboratory (United States)

Panel Discussion on Open Architecture (OA)/Open Business Model (OBM) Systems: Joint Panel with Conferences 8741 and 8754

Raja Suresh, Moderator, General Dynamics Advanced Information Systems (United States)

Bobby Junker, Office of Naval Research (United States)

Carlo Zaffanella, General Dynamics Advanced Information Systems (United States)

Howard Reichel, In-Depth Engineering Corporation (United States)

Nick Guertin, U.S. Navy (United States) 


\section{Introduction}

These are the proceedings of the eighteenth Open Architecture/Open Business Model Net-Centric Systems and Defense Transformation conference. The papers presented at the conference strongly reflected the inexorable trend towards open architecture/open business model acquisition patterns to provide the government better buying power (BBP).

The conference included the following joint sessions:

1. Open Architecture (OA)/Open Business Model (OBM) Systems, held jointly with the Unmanned Systems Technology conference. This session included keynote presentations from Dr. Bobby Junker (Office of Naval Research), Mr. Carlo Zaffanella (General Dynamics Advanced Information Systems), and Mr. Howard Reichel (In-Depth Engineering Corporation). The keynote session was followed by a panel discussion including these three gentlemen and Mr. Nickolas Guertin (U.S. Navy).

2. Networking for Netcentric Warfare, held jointly with the Ground/Air Multisensor Interoperability, Integration, and Networking for Persistent ISR conference.

The conference also included invited papers by Mr. Nickolas Guertin (U.S. Navy), Mr. Thomas Conway (PM/NV-RSTA, U.S. Army), Mr. Parag Batavia (Neya Systems LLC), Dr. William Chappell (DARPA), Mr. Tim Pavlick (IBM Corporation) and Dr. Megan Cramer (U.S. Navy PEO LCS).

Looking ahead, we expect net-centric systems to increasingly focus on open architectures (OA) and open business models (OBM). Such OA/OBM systems seek to mimic the successful PC industry and hold the promise to dramatically reduce the acquisition and life cycle costs of military systems, and tremendously accelerate the rate of technology refresh in military systems.

It is gratifying to see the high level of audience interest in this conference. Particularly gratifying is the fact that this conference has resulted in the "spin-off" of several new conferences at SPIE DSS. My sincere gratitude to the distinguished invited speakers, authors, attendees, and my associates on the program committee for another successful conference.

Raja Suresh 
Proc. of SPIE Vol. $8754875401-8$

Downloaded From: https://www.spiedigitallibrary.org/conference-proceedings-of-spie on 26 Apr 2023 Terms of Use: https://www.spiedigitallibrary.org/terms-of-use 